\title{
41資料 IID
}

<溝 義 $>$

\section{静止熱源による一次元の熱伝導*}

(フーリェ級数による取扱い)

\author{
安藤弘平** \\ Heat Conduction due to Stationary Heat Source* \\ (Treaties using Fourier's Series)
}

by Kohei Ando**

\section{I 序説}

筆者は本年 1 月号の本誌に 静止熱源による平板中の 熱伝導について基本的の事項を「講義」として記述し た1). そのとき一次元の場合については 無限板につい て述べるとともに，有限幅の板についてはフーリェ級数 によって取扱うことが便利であるととについても ある 程度述べたが, その具体的の取扱については ページ数 の関係であまり立入って誌すてとはしなかった。

本稿はその短を補ったもので, 静止熱源による一次元 の熱伝導を主としてフーリェ級数によって解いている. もっ上す簡単な場合としては Fig. 1(a).のように 熱が 板の端面 AA $(x=0)$ 飞投与され，乙れが $x$ 方向に伝 導して $x$ に沿う温度分布が Fig. 1(b) のようになる場 合であるが，本稿では Fig. 2 のように熱が $x=0 \sim x_{0}$ の領域に投与される場合む取报っている。

本稿の目的とする所は 最終的にはアーク溶接におけ る母板の熱稬を笕明するための温度分布についての知見 を得る点にあるが，その第一步として静止熱源による一
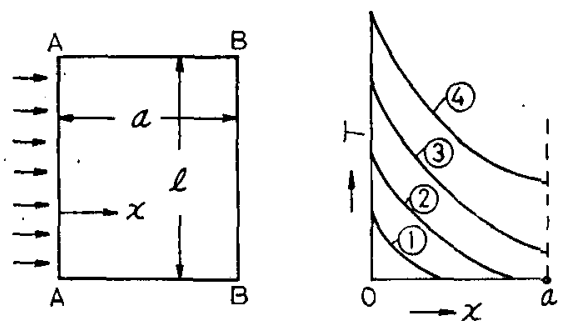

第 1 図 端面 AA の加熱

*原稿受付 昭和 45 年 7 月 9 日

**开, 具大阮大学工学部 Member, Faculty of Engineering, Osaka University

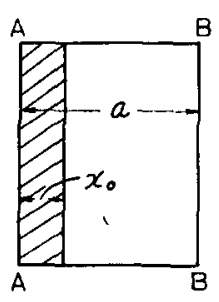

第 2 図 $x=0 \sim x_{0}$ の加熱

次元の熱伝導を取扱ったのである。

まず初めに熱が $t=0$ の瞬間に瞬間的に投与された 場合を亚節に述べ，そてでは主としてフーリェ級数の取 扱いに関して記述している。N節では熱が $t=0 \sim t$ の 期間にわたって持続投与された場合について論考してい る．III，JV節では板の表面からの熱放散を無視している が，V節にてれを考虑した場合を誌している，実際の溶 接母板では表面からの熱放散は無視し得ない場合が多い ようである。

熱の供給を停止した後の温度変化は容易に計算できる ので, ページ数の関係で省いている.

実は筆者は 本稿の平板の場合ではなく，円柱体の焬 合の熱伝尊について 他の協力者と連名で本誌に等稿し ている.本稿と同時にての11月号に揭載されるはずであ るが, 本稿は一次元の場合で, sine, cosine などフーリ エ級数による取扱である. 円柱体の場合は二次元で，ぶ ッセル函数による取扱である。崡数の差はあるが，基本 的には似たものである。

\section{II 本稿の記述の範囲} 一仮定条件一記述順序一主なる記塄一

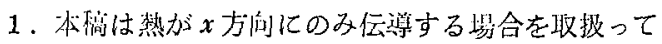


いる．板の表面からの熱放散の影響は後にV節にふれ， 初めのIII，IV節では熱放散を無視して考察を進めてい る.

2. $x$ 方向の板幅は $a$ とし，熱は Fig. 1 (a) のよう に $x=0$ なる端面住中集中的に与えられる場合之， $x=0$ 〜 $x_{0}$ なる部分に等斉に与えられる場合とを考察している.

3、 $x=a$ なる端面では 熱絶縁されている場合 $(h=$ 0）および水冷などの手段によって温度上昇が零に保た れている場合 $(h=\infty)$ について検討している.

$x=a$ なる端面が水冷されていて，端面の温度上昇に 応じて熱が冷却水へ放散される場合（ $h=$ 一定）には触 れていない，放散係数 $h$ が $h=0 ， \infty$ なる両極端の場 合のみを取扱っている.

4. $x=0 \sim a$ の全区間は一定媒質で, 熱伝尊定数は一 定としている，(つまり鎘板と銅電極が接しているよう な場合の熱伝㮈にはふれていない）

5. 熱が $t=0$ の時刻に瞬間的に投与された場合之 $t=0 \sim t$ の期間にわたって持続的に投与された場合とに ついて検鲴している.

この後者の場合の温度は 前者の埸合の解が既知なら ばその時間積分として容易に求められる，それ故に本 稿ではまず初めに節に前者の場合 すなわち $t=0$ の 時刻に熱か瞬間的に投与された場合を述べている。

6. 本稿のIII, IV節は別稿の円柱体の場合の熱伝導の 记述に対応している。

使用記号 使用した記号の主なるすのは次の通り．

$T, T^{\prime}$ ：温度上昇. $T^{\prime}$ は板表面加らの熱損失を考え た場合（ $t=0$ では $T=0$ と仮定している. $)$

$T_{0 f}, T_{0 f^{\prime}}: x=0$ 点の $t=\infty$ における温度上昇. ただ

し $h=\infty$ の場合. $T_{0 f} f^{\prime}$ は表面の熱放散を考 えた場合

$T_{m}:$ フーリ工級数の $m$ 次の温度調波の振幅

$m$ : フーリ $匚$ 級数の次数. $(3 \cdot 19) \sim(3 \cdot 20)$ 式.

$A_{m}$ : 瞬間投与熱源の場合の第 $m$ 次振幅. 無次元量. $(3 \cdot 15)$ 式, (3.23), (3.25) 式

$B_{m}$ : 持続投与の場合の第 $m$ 次振幅, 無次元量. $(4 \cdot 16) \sim(4 \cdot 21)$ 式参照.

$h: h=0$ は $x=a$ なる端面が熱絶縁されている場 合, $h=\infty$ は $x=a$ 点が $T=0$ に保たれてい 当場合. $(3 \cdot 3) \sim(3 \cdot 5)$ 式

$t \quad:$ 時間

$\tau_{1}$ ：時間定数．基本波に対するあの．熱放散のない 場合. (3.9) 式参照.

$\tau_{m}, \tau_{m}{ }^{\prime}$ : 時間定数 $(3 \cdot 13),(5 \cdot 12)$ 式参照. $\tau_{\mathrm{rad}}$ : 表面加らの熱放散に関する時間定数 $(5 \cdot 4)$ 式.

$f: f=\tau_{1} / \tau_{\mathrm{rad}}(5 \cdot 13)$ 式.

$R_{0}: R_{0}=x_{0} / a$. 熱源の偪の比率 $(3 \cdot 21)$ 式.

$q$ : 持続発熱の埸合の発熱密度 $\mathrm{cal} / \mathrm{cm}^{3} \cdot \mathrm{sec}$

$q_{0} \quad$ : 熱が Fig. $1 \mathrm{AA}$ 端面に集中した場合の発熱密 度 $\left(q_{0}=q x_{0}\right) \cdot \mathrm{cal} / \mathrm{cm}^{2} \cdot \mathrm{sec} .(4 \cdot 13)$ 式.

$r:(5 \cdot 17),(5 \cdot 19)$ 式.

\section{III 瞬間投与の熱源の場合}

（a）温度の基本方程式，初期条件，境界条件

熱が $x$ 方向にのみ伝導する場合を考えると，任意の点 $x$ の時刻 $t$ に抢ける温度 $T$ は 熱伝導の基本式として 次の関係を満足していなければならぬ（（平板の表面か らの熱放散は後に考えるとして，乙こではしばらく こ れを無視して考える．)(持続的の発熱のない場合)

$$
\frac{\partial T}{\partial t}=k \frac{\partial^{2} T}{\partial x^{2}}
$$

ただし $k$ 注熱伝達率， $k=K / c \sigma$.

ここでは $t=0$ の瞬間住が Fig. 2 のハッチの部分 に瞬間的に与えられた場合 その後の温度変化を考える わけで，上式を解くための初期条件は

$$
\left.\begin{array}{rl}
t=0: x=0 \sim x_{0} \text { では } & T=T_{0} \\
x=x_{0} \sim a & \text { では } \\
T=0
\end{array}\right\}
$$

である。

時間が経過すると，熱は $x=a$ 点にも伝導してくる. むしての $x=a$ 点が冷却水に接していると，その点の温 度上声 $T$ 亿比例して熱が泠却水へ放散される。したが って $x=a$ なる点の境界条件として，一般に

$$
-\left.\frac{\partial T}{\partial x}\right|_{x=a}=h T
$$

が成立する、本稿では $h=0, \infty$ の両極端の場合のみ を考察し， $h$ が任意の一定值の場合は若えていない.

$h=0$ は上式からわかるように $x=a$ 点の温度傾斜 が零で, $x=a$ 面が熱絶縁されている場合を意味し， $h=\infty$ は， $T=0$ を意味している．乙れはなんらかの手 段によって $x=a$ 面を完全に冷却してその温度を零に保 った場合を指している。すなわち

$$
\begin{aligned}
& h=\infty:\left.T\right|_{x=a}=0 \\
& h=0:\left.\frac{\partial T}{\partial x}\right|_{x=a}=0
\end{aligned}
$$

実際の溶接板については $h=\infty$ よりは $h=0$ の条 件にはるかに近いが，ここでは抵抗溶接にお范る水冷電 極のととも考え，その極端な場合として $h=\infty$ の場合 をあ考える。

\section{(b) 温度の方程式の特解}

今かりに $t=0$ における $x$ 亿沿う温度分布が Fig. 3 （a）の実線のようで，乙れが cosine 波として 


$$
T=T_{1} \cdot \cos \left(\frac{\pi}{2} \cdot \frac{x}{a}\right) \quad(x=-a \sim+a) \cdots(3
$$

であったとし，さらにもし $x= \pm a$ 点の温度は 水冷 その他のなんらかの方法で 常に

$$
T=0
$$

に保たれているすのとすれば，その後 時間が経過した ときの温度は次式で与えられる。

$$
T=T_{1} \cdot \cos \left(\frac{\pi}{2} \cdot \frac{x}{a}\right) \cdot e^{-\left(k \pi^{2} / 4 a^{2}\right) \cdot t}
$$

なんとなれば，上式は $t=0$ においては（3・6）式と なり初期条件を満足し，任意の時刻 $t$ において基本式 (3.1) 式の関係を満足し，加境界条件（3.4）式を満 足しているから正解である。

さて上式の指数項に注目し，

$$
\frac{4 a^{2}}{k \pi^{2}}=\tau_{1}
$$

とおくと（3.8) 式は次のようにかける.

$$
T=T_{1} \cdot \cos \left(\frac{\pi}{2} \cdot \frac{x}{a}\right) \cdot e^{-t / \tau_{1}}
$$

(3.9) 式のて1 は時間の次元を有し，熱時間定数之呼 ばれている. Fig. $3(a)$ の点線は $t=\tau_{1}$ なる時刻にお ける温度で, すべての点の温度は $t=0$ に此べて $e^{-1}=$ 0.367 倍となり, cosine 波はくずれていない.

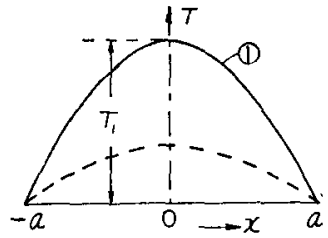

(a)

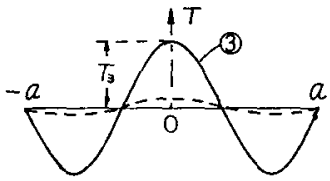

(b)

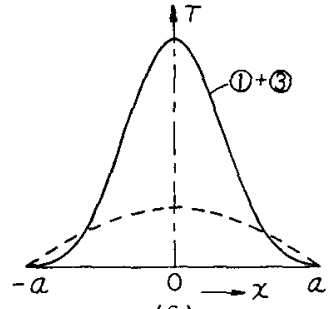

(c)

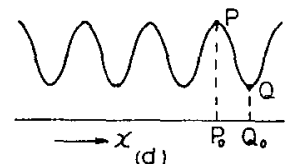

(d)
第 3 图 $t=0$ の埧度が正弦波分布をしている場合

今もし $t=0$ における温度分布が Fig. 3 (a) ではな く（b）の実線（曲線(3) のようであるとし，

$$
T=T_{m} \cdot \cos \left(m \cdot \frac{\pi x}{2 a}\right)
$$

であるとすると，その後の盜度は次式で与えられる。

$$
\begin{aligned}
& T=T_{m} \cdot \cos \left(m \cdot \frac{\pi x}{2 a}\right) \cdot e^{-1 / \tau_{m}} \\
& \tau_{m}=\frac{4 a^{2}}{m^{2} \cdot k \pi^{2}}=\frac{1}{m^{2}} \cdot \tau_{1}
\end{aligned}
$$

Fig. 3(b) の点線はかりに $m=3$ Łして

$$
t=\tau_{1}=9 \tau_{3}
$$

の㭙刻における温度分布を示するので，(3.12）式の指 数項は

$$
e^{-9}=0.00012
$$

となり，t=0 の状態 (実線) に比べて極めて小さな值 となる。

Fig，3(c) の実線は（a)，(b) の実線(1)，(3)の和を示 しているが，今 $t=0$ に执いててのような温度分布であ り，かつ $x= \pm a$ において $T=0$ なる条件が充たされ ておれば， $t=\tau_{1}$ の時点では点線のようになり，第 3 高 調波は減衰していて ほとんど全く基本波のみの分布之 なる。

このように高調波が基本波に比べて速かに減衰するの はとれを熱伝導諭的にいえば次のように理解できる． すなわち今 $t=0$ において（d）因のような温度分布が あるとし， $P_{0}, Q_{0}$ 点間の温度差を考えるに，乙の温度差 は時間が経過すれば 当然 熱伝導によって解消し, 温 度は平均化する．かりに温度差は一定として距離 $\overline{\mathrm{P}_{0} \mathrm{Q}_{0}}$ が異なる場合を考えると， $\mathrm{P}_{0}, \mathrm{Q}_{0}$ 間の伝導熱は公式

$$
K \cdot \frac{d T}{d x}
$$

からわかるように， $\overline{\mathrm{P}_{0} \mathrm{Q}_{0}}$ が短いよ，それに比例して增 大する．しかるに $\overline{\mathrm{P}_{0} \mathrm{Q}_{0}}$ 閪の保有熱量は容積 $\overline{\mathrm{P}_{0} \mathrm{Q}_{0}}$ に比 例しており， $\overline{\mathrm{P}_{0} \mathrm{Q}_{0}}$ が短いと保有熱量それ自体が小さい. したがって $P_{0}, Q_{0}$ 間の温度差は $\widehat{\mathrm{P}_{0} \mathrm{Q}_{0}}$ が短い上 その 距離の 2 乗に比例して速汃に解消し平均化するのであ る*.

さて一般に $t=0$ における $x$ に沿う温度分布

$$
T=T_{0} \cdot f(x)
$$

が与えられていると，この $f(x)$ は後揭（3.16）式のよ うにフーリェ級数として表示できる。したがって $t \geqslant 0$ における温度は次の形となる。

$$
T=T_{0} \cdot\left[A_{0}+\sum A_{m} \cdot \cos \left(m \cdot \frac{\pi x}{2 a}\right) \cdot e^{-t / \tau_{m}}\right]
$$

（c）矩形波分布曲線をフーリェ級数で表示すること Fig. 4 の太㮫線で示した矩形波は これを細線で示 した正弦波群の和としてフーリェ級数で示すととができ

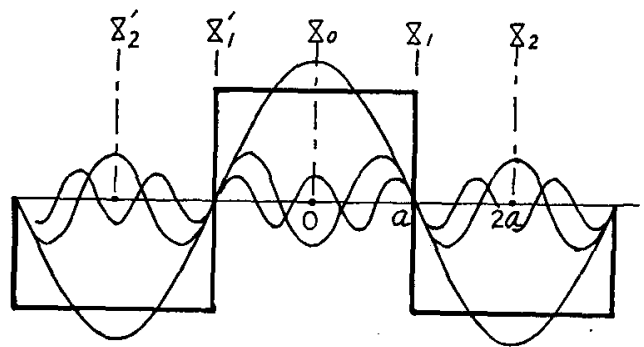

第 4 図 矩形波分布のフーリ工級数による表示

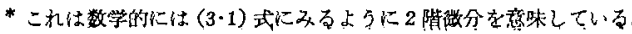




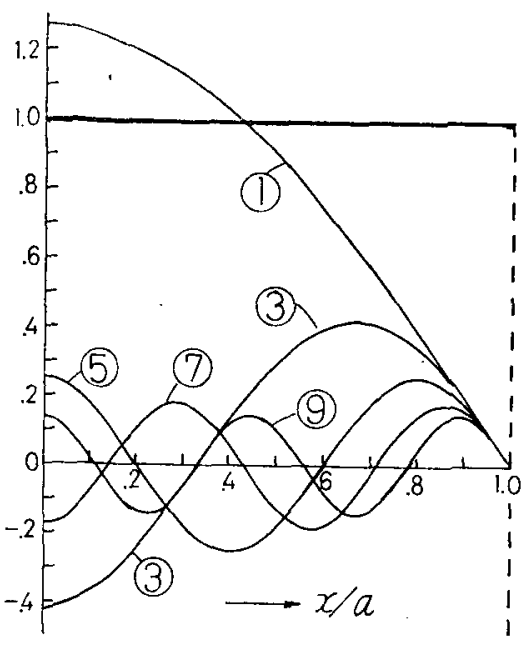

第 5 图 Fig. 4 の $\mathrm{X}_{0} \mathrm{X}_{1}$ 区間の詳緇

る. Fig. 5 は Fig. 4 の

$$
x=0 \sim a
$$

の領域を拡大して詳しく示したもので，横軸は $x$ の代り に $x / a$ なる比で示しており，縌軸はFig. 4 の矩形波の 高さを 1 として，その高さの比で示している.

次に Fig. 6 のような矩形波もやはりフーリェ級数で 示し得る. Fig. 7 は $\left(x_{0} / a\right)=1 / 2$ の場合に $x=0 \sim a$ 部分を拡大して示したあのである.

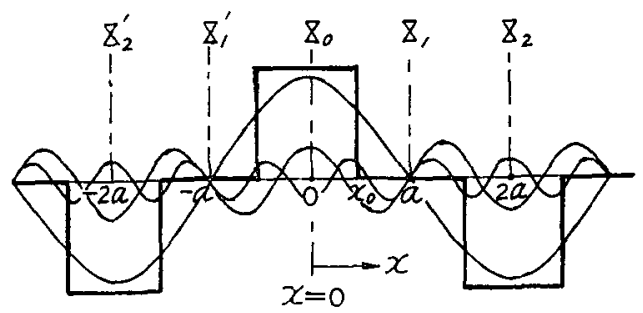

第 6 図 矩形波分存のフーリエ級数による表示

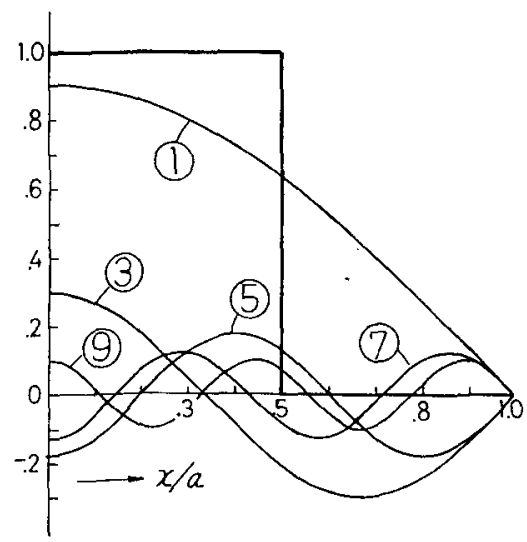

第 7図 Fig. 6 の $\mathrm{X}_{0} \mathrm{X}_{1}$ 区間の詳細
これらフーリェ級数は 数学で教えているように次の ように求めることができる，すなわち今 Fig. 6 亿打い $\tau \mathrm{X}_{0}$ 点 $\left(x=0\right.$ 点) を心中として $\mathrm{X}_{2}{ }^{\prime} \mathrm{X}_{2}$ 区間を考え， この区間の矩形波を $f(x)$ とし，区間の長さを $2 a \times 2$ と 宁ると,

$$
f(x)=A_{0}+A_{1} \cdot \cos \left(\frac{\pi x}{2 a}\right)+A_{2} \cdot \cos \left(2 \cdot \frac{\pi x}{2 a}\right)+\cdots
$$

ただし

$$
\begin{aligned}
& A_{0}=\frac{1}{2} \cdot \frac{1}{2 a} \int_{-2 a}^{2 a} f(x) \cdot d x \\
& A_{m}=\frac{1}{2 a} \int_{-2 a}^{2 a} f(x) \cdot \cos \left(m \cdot \frac{\pi x}{2 a}\right) \cdot d x
\end{aligned}
$$

(c-1) 境界条件と $m$ 值 上式において $m$ はもとよ り正の整数であるが， $x=a$ 点の境界条件 $h=\infty, 0$ に応 じて $m$ は

$$
\begin{array}{ll}
h=\infty & : m=\text { 奇数 } \quad m=1,3,5 \ldots \\
h=0: m=\text { 偶数 } \quad m=2,4,6 \ldots
\end{array}
$$

となる. 何となれば $m=$ 奇数 ならば $(3 \cdot 15)$ 式の cosine $x=a$ に执いて 0 となり，T=0なる境界条 件を満足する。また $m=$ 偶数ならば, cosineは $x=a$ において最大となり, cosine $x$ について微分した sine は零となり， $\partial T / \partial x=0$ なる境界条件を满足する。 (3.5) 式参照*.

* 上述のように $h=0$ の場合は $m=2,4, \cdots$ となる 加 $n=m / 2$ とおくと， $n=$ 整数 $=1,2,3 \cdots$ とな b, cosine の項は

$$
\cos \left(m \frac{\pi x}{2}\right)=\cos \left(n \frac{\pi x}{a}\right) \quad n=1,2,3
$$

なる形にかける。

今 温度分布として Fig. 8 のようなすの すな わち $\mathrm{X}_{1}(x=a)$ 点を中心として左右対称なものを 仮想すると， $x=a$ 点では左方 $\mathrm{X}_{0}$ 附近の温度による 伝導熱之, 右方 $\mathrm{X}_{2}$ 附近からの伝導熱とが相等しく なり，左右相殺されて $x=a$ では熱の移動はなく， (3.5) 式が満足される。 $\mathrm{X}_{2}$ 附近の温度分布は $\mathrm{X}_{0}$ 附 近のそ机に対して「正」の映像として動作してお り，フーリェ級数としては $\mathrm{X}_{0} \mathrm{X}_{1}$ 間を $180^{\circ}$ (基本 波）として取扱ってよい:

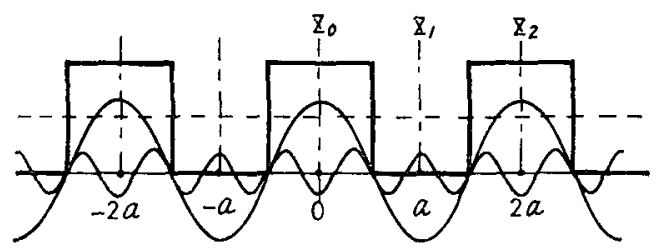

第 8 図 $x=a$ 点で熱絶縁されている場合の考え方

これに反して Fig. 6 では $\mathrm{X}_{2}$ 附近の温度分布は $\mathrm{X}_{0}$ 附近のそれに対して負の映像として働いてお り， $\mathrm{X}_{0} \mathrm{X}_{2}$ を $180^{\circ}$ (基本波) としなければならぬ.

ことでは $h=0, h=\infty$ の両者を考えて行くの で, $\mathrm{X}_{0} \mathrm{X}_{2}=2 a$ 区間を $180^{\circ}$ (基本波) とし， $h=0$ の場合には $m=2,4,6$ として取扱うとととする。 
Fig. 9 は その初期分布は Fig. 7 とまったく同じで あるが， $x=a$ なる境界条件を $h=0$ とした場合を示し ている. 図の@なる水平線は（3・15）式の $A_{0}$ を示して いる。

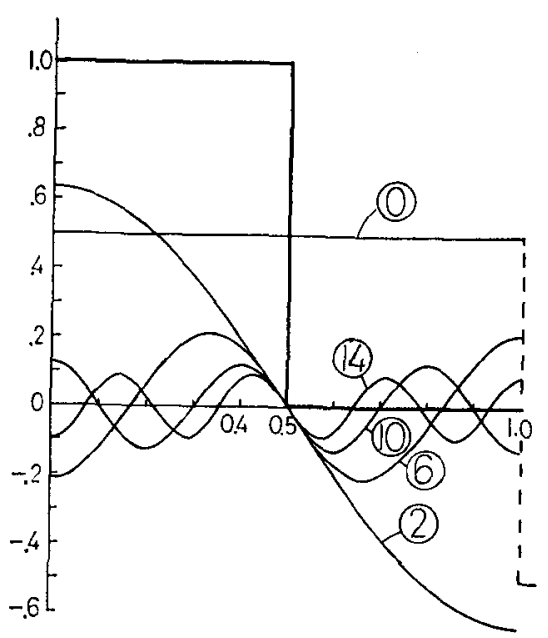

第 9图 Fig. 8 の $\mathrm{X}_{0} \mathrm{X}_{1}$ 区間の詳細

\section{(c-2） フーリェ級数の各項の振幅}

(3・15) 式にみるフーリ土級数の各項の振幅 $A_{m}$ は （3・18）式によって計算できる. 今 熱の発生領域 $x_{0}$ (Fig. 2 参照) と板幅 $a$ との比を

$$
R_{0}=x_{0} / a
$$

として示し， $x=0 \sim x_{0}$ では等密な温度分布（矩形波） であり, $x=x_{0} \sim a$ では熱の発生はないるのとすると， $(3 \cdot 18)$ 式の $f(x)$ は

$$
\left.\begin{array}{ll}
x=0 \sim x_{0}: & f(x)=1 \\
x=x_{0} \sim a: & f(x)=0
\end{array}\right\}
$$

とおいて， $A_{m}$ は（3.18）式によって次のようになる.

$$
A_{m}=\frac{1}{m} \cdot \frac{4}{\pi} \cdot \sin \left(m \frac{\pi}{2} \cdot R_{0}\right)
$$

また（3.17）式の $A_{0}$ は $h=\infty, h=0$ に応じて, そ れぞれ Fig. 6, Fig. 8 を考え

$$
\left.\begin{array}{ll}
h=\infty: & A_{0}=0 \\
h=0: & A_{0}=R_{0}
\end{array}\right\}
$$

Fig. 10 は（3.23）式の $A_{m}$ を図解するあので，図 の正弦波内に示した縱線分の長さは $(3 \cdot 23)$ 式の $\sin$ $\left(m \pi R_{0} / 2\right)$ を示しており， $A_{m}$ はとの線分の長さに $(4 / m \pi)$ を乗じたものよなる。

後掲第 1 表には $R_{0}=0.3$ の場合について $A_{m}$ その他 の值を示している。

Fig. 11 は $h=0$ で $R_{0}=1 / 4$ の場合の波形を示して いる。

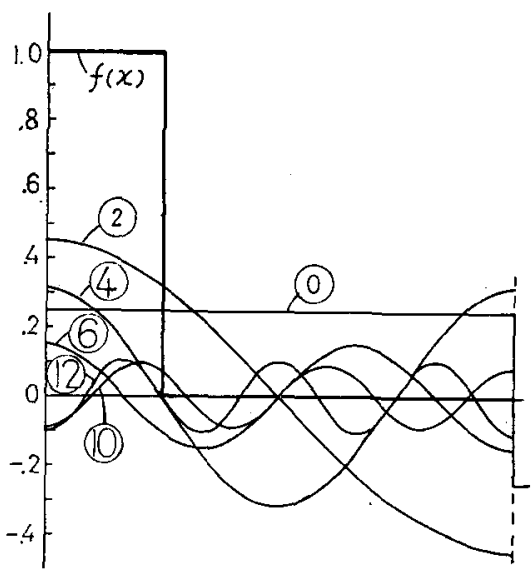

第11図 $R_{0}=1 / 4, h=0$ の場合

(d) 温度の時間的変化

Fig. 12 は $t=0$ 亿おける温度分布が $R_{0}=1 / 2$ なる 矩形波 (Fig. 7, 9) の場合の その後の温度变化を示し
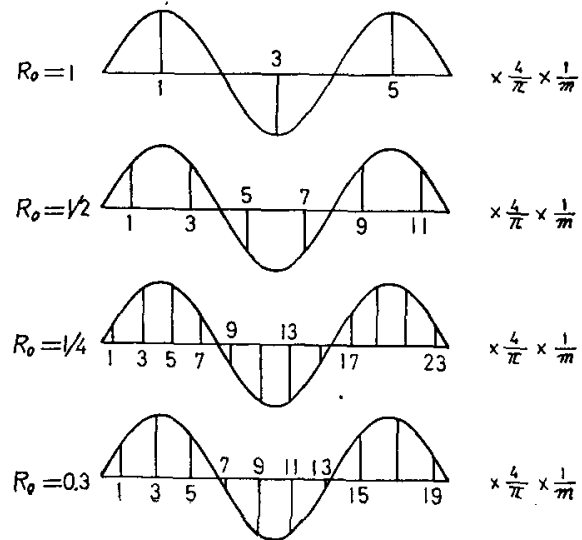

(a) $h=\infty$
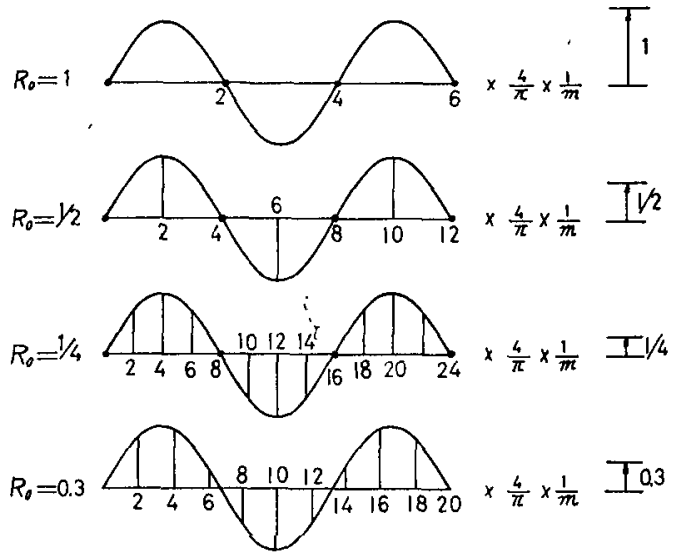

(b) $h=0$

第10図 フーリエ級数の振幅 $A_{m}$ の大きさの説明図 


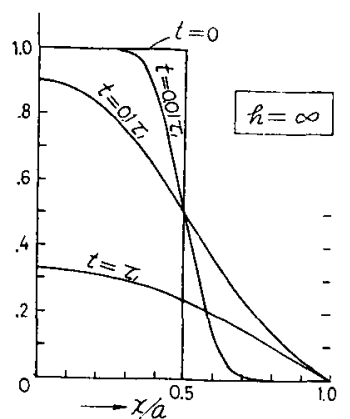

(a) $h=\infty$

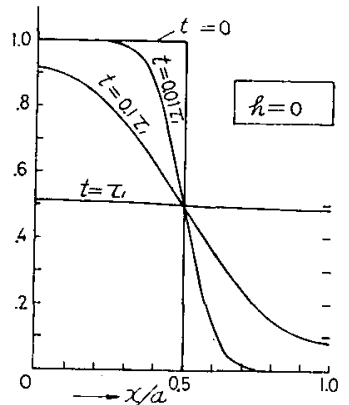

(b) $h=0$
第12図 $t=0$ における分布が図のような矩形波 $\left(R_{0}=1 / 2\right)$ の場合の $t=0.01 \tau_{1}, 0.1 \tau_{1}$ $\tau_{1}$ における温度分布

ている.（a) は $h=\infty$ の場合で, フーリェ級数は $m=$ 1, 3,5 …゙でるが，すで飞 Fig. 3 について述べたよう に, $t=\tau_{1}$ では基本波 $(m=1)$ は初めの值の $e^{-1}=0.368$ 倍となるに対して第 3 高調波 $(m=3)$ は $e^{-9}=0.0001$ 倍となり，温度分布曲線はほとんど全く正弦波となって いる. このときの $x=0$ 点の值は 0.333

(b) 図は $h=0$ の場合で, $m=0,2,4 \cdots$ であるが, $m=2$ 調波は $t=\tau_{1}$ の時刻では 初めの值の $e^{-4}=0.018$ 倍となり， $m=4,6$ などの調波はもちろん極めて小さく なっており，ほとんど $A_{0}$ 亿近くなっている。

図には $t=0.01 \tau_{1}$ の場合も示されているが, 分布斗 線は初めの $t=0$ のときの矩形波加らあまり変っていな い. 熱はいまだほとんど $x=a$ には伝わっておらず， したがって $x=a$ 点の条件の差 $(h=\infty, 0)$ は効かず, 分布曲線の形は $h=\infty, 0$ においてほとんど全く同じで ある.

$t=0.1 \tau_{1}$ では 図に見るように $h=\infty, 0$ なる境界条 件の差は $x=a$ 附近では現われている. 案外（?）に 早く両者の差が現れてくる.

(e) 熱が $\boldsymbol{x}=0$ なる端面に集中的に与えられる場合 前項までに述べる所は $t=0$ における温度分布が Fig. 7, 9,11 のような矩形波分布の場合であるが，今

Fig. 2 のハッチ幅 $x_{0}$ が $x_{0} \rightarrow 0\left(R_{0} \rightarrow 0\right)$ の場合を考え てみる.しからば (3.23) 式の $A_{m}$ は

$$
\begin{aligned}
A_{m} & =\frac{1}{m} \cdot \frac{4}{\pi} \cdot \sin \left(m \cdot \frac{\pi x_{0}}{2 a}\right) \rightarrow \frac{1}{m} \cdot \frac{4}{\pi} \cdot m \frac{\pi}{2} \cdot \frac{x_{0}}{a} \\
& =2 x_{0} / a
\end{aligned}
$$

$t=0$ におけるハッチ部分の保有熱量を $Q_{0}$ （板厚 $1 \mathrm{~cm}$ についての値) とすると, その部分の温度 $T_{0}$ は

$$
T_{0}=Q_{0} / c \sigma x_{0}
$$

それ故に温度のうち第 $m$ 項の振幅は

$$
T_{m}=T_{0} A_{m}=\frac{Q_{0}}{c \sigma x_{0}} \cdot \frac{2 x_{0}}{a}=2 \frac{Q_{0}}{c \sigma a}=2 T_{a v 0}
$$

ただしここに $T_{a v 0}$ は熱量 $Q_{0}$ が板全体に与えられた 場合の平均温度.

上のように振幅 $T_{m}$ が $m$ に無関係に一定となるの で, 温度は次のように与えられる。

$$
\begin{array}{r}
h=\infty \quad T=2 T_{a v 0} \cdot \sum \cos \left(m \cdot \frac{\pi x}{2 a}\right) \cdot e^{-t / \tau_{m}} \\
m=1,3,5 \\
\cdots \cdots \cdots \cdots(3 \cdot 27) \\
h=0 \quad T=2 T_{a v 0} \cdot\left[\frac{1}{2}+\sum \cos \left(m \cdot \frac{\pi x}{2 a}\right)\right] \cdot e^{-t / \tau_{m}} \\
m=2,4,6
\end{array}
$$

Fig. 13 は $t=0$ における温度分布をフーリェ級数で 示したすのである.との温度は 実際には $x=0$ 点に おいて $T=\infty$ で, 他の点では $T=0$ であるととはい うまでもない。

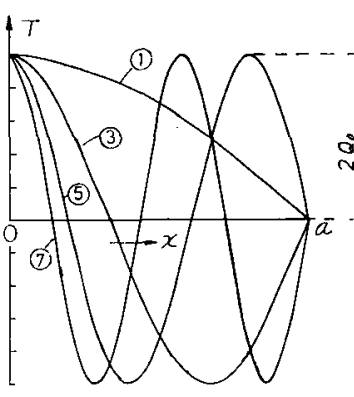

(a) $h=\infty$

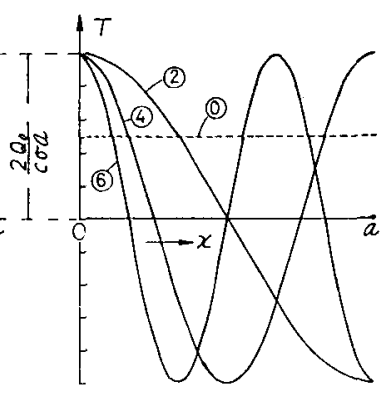

(b) $h=0$
第13図 熱が $x=0$ 端面に集中された場合の フーリエ級数に上る表示

\section{IV 持続発熱の場合の温度上昇}

前䬦に述べる所は $t=0$ の瞬間に熱を瞬間的に投与 した場合についてであるが， $t=0 \sim t$ の期間にわたって 一定割合で熱 $(\mathrm{cal} / \mathrm{sec})$ を投与した場合の温度は 前節 の結果から容易に計算できる。乙の過渡的温度上昇につ いて述べるに先だって，記述の便宜上まず時間がじゅう 分長く経過した準定常状態の温度上昇について一言す る.

\section{（a）準定常状態の温度上昇}

（a-1） $\boldsymbol{h}=\infty$ の場合 一定熱量 $q \mathrm{cal} / \mathrm{cm}^{2} \cdot \mathrm{sec}$ が $0 \sim t$ にわたって $x=0 \sim x_{0}$ 区間に投与されるとき, $x=a$ の端面温度が $T=0$ に保持されているとき, $t=\infty$ とした準定常状態の温度上昇は

$$
\begin{aligned}
& x=x_{0} \sim a: . \quad T_{f}=\frac{q x_{0}}{K}(a-x) \\
& x=0 \sim x_{0}: \quad T_{f}=\frac{q x_{0}^{2}}{2 K}\left(1-\frac{x^{2}}{x_{0}^{2}}\right)+\frac{q x_{0}}{K}\left(a-x_{0}\right) \cdots
\end{aligned}
$$


となる*. $x=0$ 点の湿度を $T_{0 f}$ とかくと, 上式から

$$
T_{0 f}=\frac{q x_{0} a}{K}\left(1-\frac{1}{2} R_{0}\right)
$$

（a-2） $\boldsymbol{h}=0$ の場合 この域合には $\boldsymbol{x}=\boldsymbol{a}$ 端面が熱 絶縁されているので， $0 \sim x_{0}$ 区間の発熱のために板全体 の温度は時間とともにドンドン上昇する（板表面からの 熱放散は無視)。0〜 $x_{0}$ 区間の発熱は $q x_{0}$ であるので， 板全体の温度上昇速度は

$$
\text { 温度上昇速度 }=\frac{q x_{0}}{c 0 a}
$$

今 $x=a$ 点の温度を基準として，乙れに対する他の 点の温度上昇を $\Delta T$ で示すと，

$$
\begin{array}{ll}
x=x_{0} \sim a & \Delta T_{f}=\frac{q x_{0} a}{2 K} \cdot\left(1-\frac{x}{a}\right)^{2} \\
x=0 \sim x_{0} & \Delta T_{f}=\frac{q x_{0} a}{2 K}\left(1-\frac{x_{0}}{a}\right)\left(1-\frac{x^{2}}{a x_{0}}\right)
\end{array}
$$

となる**. $x=0$ の $\Delta T_{f}$ を $\Delta T_{0 f}$ としてボすと，

$$
\Delta T_{0 f}=\frac{q x_{0} a}{2 K} \cdot\left(1-\frac{x_{0}}{a}\right)
$$

これを（4·3）式の $T_{0 f}$ と比較すると

$$
\frac{\Delta T_{0 f}}{T_{0 f}}=\begin{aligned}
& 1-R_{0} \\
& 2-R_{0}
\end{aligned}
$$

(a-3) $\boldsymbol{R}_{0} \rightarrow 0\left(x_{0} \rightarrow 0\right)$ の場合（発熱が $x=0$ 端面に 集中した場合）今 $0 \sim x_{0}$ 区間の発熱量 $q x_{0}$ を

$$
q_{0}=q x_{0}
$$

なる記号で示すと，上に求めた結果は $x_{0} \rightarrow 0$ のとき

$$
h=\infty \quad T_{f}=T_{0 f}\left(1-\frac{x}{a}\right) \quad T_{0 f}=\frac{q_{0}}{K} a
$$

* 上式が正しいことは 上式を $x$ について貒分してみ るとただちに理解できる、すなわち

$$
\begin{aligned}
& \text { (4.1) 式: }-\frac{d T_{f}}{d x}=\frac{q x_{0}}{K} \\
& \text { (4.2) 式: }-\frac{d T_{1}}{d x}=\frac{q x}{K}
\end{aligned}
$$

(4·4) 式の $q x_{0}$ は 0〜 $x_{0}$ 区間の発生熱で, $x=x_{0}-a$ 区間ではこの熱が $x=a$ の方へ伝導するから $(4 \cdot 4)$ 式が成立する。また $(4 \cdot 1)$ 式は $x=a$ にて $T=0$ であり，境界条件を満足している．したがって正解 である.(4.5) 式についてあ同様.

**上式を $x$ について微分してみると

$$
\begin{aligned}
& (4 \cdot 7) \text { 式: }-\frac{d \Delta T_{f}}{d x}=\frac{q x_{0}}{K}\left(1-\frac{x}{a}\right) \\
& \text { (4.8) 式: }-\frac{d \Delta T_{f}}{d x}=\frac{q x}{K}\left(1-\frac{x_{0}}{a}\right)
\end{aligned}
$$

(4·11) 式は全発生熱 $q x_{0} の う(1-x / a)$ 分が $x$ 点 を通って $x$ 以遠へ伝贈されるとして成立し，(4. 12）式は $x$ 点までの発生熱 $q x$ のう $\left(x_{0} / a\right)$ 分は その部分の温度上舁のために消費せられ，(4.6) 式 参照, その残余 $\left(1-x_{0} / a\right)$ が $x$ 点以遠へ伀導され るとして理解できる。(4·7)，(4.8) 式は上の基本 閔䋆式を満足し，かつ境界条件を満足しているから 西解である。

$$
h=0 \quad \Delta T_{f}=\Delta T_{0 f}\left(1-\frac{x}{a}\right)^{2} \quad \Delta T_{0 f}=\frac{1}{2} T_{0 f} .
$$

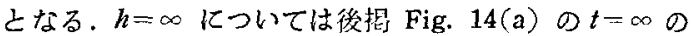
明線， $h=0$ については油線(2)参照.

（b）温度上昇の理諭式 $t=0$ における温度上显は零

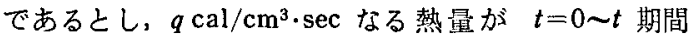
にわたって $x=0 \sim x_{0}$ 区間に発生したときの時刻 $t$ に おける温度上昇は 前節に求めた瞬間投与の温度の式を $0 \sim t$ について侍間皘分することによって次のように求 められる.

$$
\frac{T}{T_{0 f}}=B_{0}{ }_{\tau_{1}}^{t}+\Sigma B_{m} \cdot \cos \left(m \cdot \frac{\pi x}{2 a}\right)\left(1-e^{-t / \tau_{m}}\right)
$$

ただし $T_{0 f}$ は $h=\infty$ の場合の $x=0$ 点の $t=\infty$ の温 度上䒜であり，(4-3) 式， $B_{0}, B_{m}$ は次の通りである*。

$$
\begin{aligned}
B_{0} & =0 \quad(h=\infty) \\
& =\frac{4}{\pi^{2}} \cdot \frac{1}{1-R_{0} / 2} \quad(h=0) \\
B_{m} & =\frac{16}{\pi^{3}} \cdot \frac{1}{m^{3}} \cdot \frac{\sin \left(m \cdot \frac{\pi}{2} \cdot R_{0}\right)}{R_{0}\left(1-R_{0} / 2\right)}
\end{aligned}
$$

第 1 表には $R_{0}=0.3$ の場合の $A_{m}, B_{m}$ を示してい

* 今 $t=0 \sim t$, の間の任意の時刻 $\tau$ と $\tau+d \tau$ との間

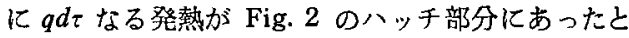
すると，その瞬間には その部分は

$$
d T_{0}=q d \tau / c \sigma
$$

だけ温度上杽する。てれは $x=0 \sim x_{0}$ の区間の矩 形波分布であるから，それより $(t-\tau)$ だけ時間が 経過した瞬間 $\tau+(t-\tau)=t$ の時刻には，任意の点 $x$ の温度は $(3 \cdot 15)$ 式の $T_{0}$ の代りに上の $d T_{0}$ を, $t$ の代りに $(t-\tau)$ を代入したものとなる。

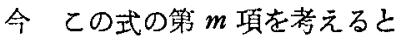

$$
d T_{m}=d T_{0} \cdot A_{m} \cdot \cos \left(m \cdot \frac{\pi x}{2 a}\right) \cdot e^{-(t-\tau) / \tau_{m}}
$$

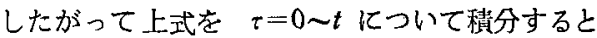

$$
\begin{aligned}
T_{m} & =\int_{0}^{t} d T_{m}=\int_{0}^{t} \frac{q}{c \sigma} \cdot A_{m} \cdot \cos \left(m \frac{\pi x}{2 a}\right) e^{-(t-\tau) / \tau_{m}} \cdot d \tau \\
& =\frac{q}{c \sigma} \cdot A_{m} \cdot \tau_{m} \cdot \cos \left(m \frac{\pi x}{2 a}\right)\left(1-e^{-t / \tau_{m}}\right) \cdots(4 \cdot 20)
\end{aligned}
$$

上式上 (4.3) 式の $T_{0 f}$ との此をとると, $(4 \cdot 16)$ 式の $B_{m}$ は

$$
B_{m}=\frac{a}{c \sigma} A_{m} \cdot \tau_{m} \div\left\{\frac{q x_{0} a}{K} \cdot\left(1-\frac{1}{2} R_{0}\right)\right\}
$$

上式の $A_{m}, \tau_{m}$ に $\left.(3 \cdot 23) （ 3 \cdot 13\right)$ の関係を代入 すると，上式は (4·18) 式となる。

次に (4.17) 式の $B_{0}$ についてであるが，(4.16) 式の第 1 項は (3.15) 式の $A_{0}$ についての積分と $T_{\text {of }}$ との比で,

$$
\frac{q}{c \sigma} \cdot \frac{A_{0} \cdot t}{T_{0 f}}
$$

である、矩形波についての $A_{0}$ は $A_{0}=R_{0}$ なるとと に留意し， $T_{0 f}$ として $(4 \cdot 3)$ 式を代入すると， $B_{0}$ として $(4 \cdot 17)$ 式を得る、 
第 1 表 $R_{0}=0.3$ の埸合の $A_{m}, B_{m}$ の值

\begin{tabular}{r|c|c|c|c}
\hline \hline$m$ & \multicolumn{2}{|c|}{$h=\infty$} & \multicolumn{2}{|c}{$h=0$} \\
\cline { 2 - 4 } & $A_{m}$ & $B_{m}$ & $A_{m}$ & $B_{m}$ \\
\hline 0 & .578 & .919 & .300 & .477 \\
1 &. & & .514 & .204 \\
2 &. & .074 & .302 & .030 \\
3 & .419 & .011 & & .003 \\
4 & .180 & & .066 & .003 \\
5 & & & -.001 & -.002 \\
7 & -.028 & -.001 & & -.002 \\
8 & & -.002 & -.127 & -.002 \\
9 & -.126 & &
\end{tabular}

る. $B_{m}$ は $(4 \cdot 18)$ 式に見るように $m^{3}$ に反比例し, 高 次のあのは $A_{m}$ よりもはるかに急速に減少してゆく. したがって温度上茬の概算法としては (4.16) 式の初め の1〜2 項のみをとればよいととになる。

第 2 表には $R_{0}=1,0.5,0.3,0$ の堭合の $B_{0}, B_{m}$ 值 を示している。

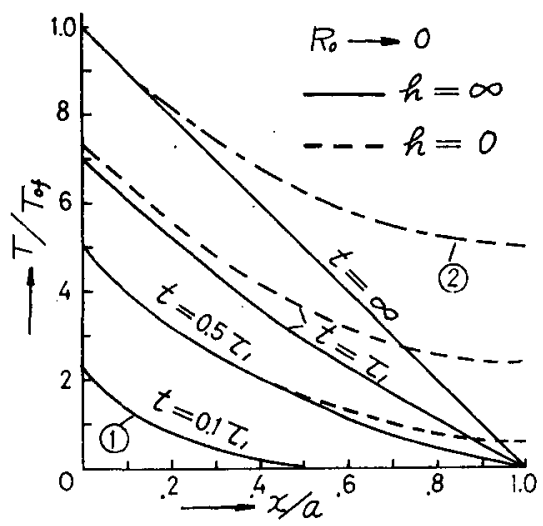

(a) $R_{0}=0$

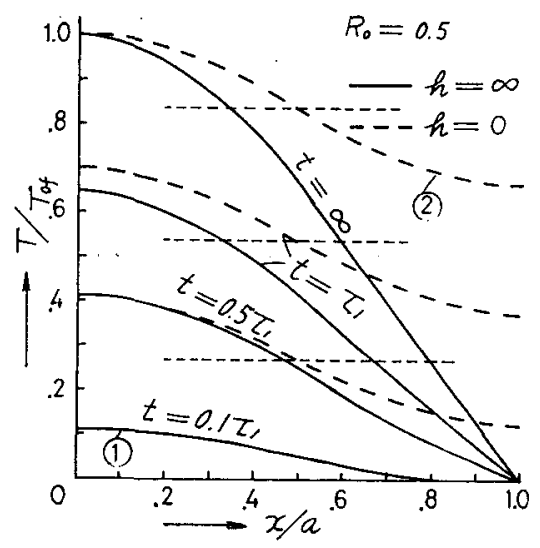

(c) $R_{0}=0.5$
第 2 表 三三の $R_{0}$ に対する $B_{m}(m=0 \sim 7)$ の值

\begin{tabular}{c|cccc|cccc}
\hline \hline$R_{0}$ & 1 & .5 & .3 & 0 & 1 & .5 & .3 & 0 \\
\hline$m$ & & \multicolumn{2}{c|}{$h=\infty$} & & \multicolumn{5}{|c}{$h=0$} \\
\hline 0 & & & & & .811 & .540 & .477 & .405 \\
1 & 1.032 & .973 & .919 & .811 & & & & \\
2 & & & & & 0 & .170 & .204 & .203 \\
3 & -.038 & .036 & .074 & .090 & & & & \\
4 & & & & & 0 & 0 & .030 & .051 \\
5 & +.008 & -.008 & .011 & .032 & & & & \\
6 & & & & .006 & 0 & -.003 & .023 \\
7 & -.003 & -.003 & -.001 & .017 & & & & \\
\hline
\end{tabular}

\section{（c）温度上昇の変化過程}

Fig. 14(a) (d) は $R_{0}=x_{0} / a$ の二三の值 $\left(R_{0}=0\right.$, $0.3,0.5,1.0)$ に対する温度分布を 時間をパラメータ として示したものである. 実線は $h=\infty$ の場合, 点線 は $h=0$ の場合を示している. 縦軸の温度上昇 $T$ は $T_{0 f}$ の比で示しているが, この $T_{0 f}$ はすでに述べたよ うに $h=\infty$ の場合の $x=0$ 点の定常温度上茬である.

(この $T_{0 f}$ は $R_{0}$ によってその絶刘值が異なることは

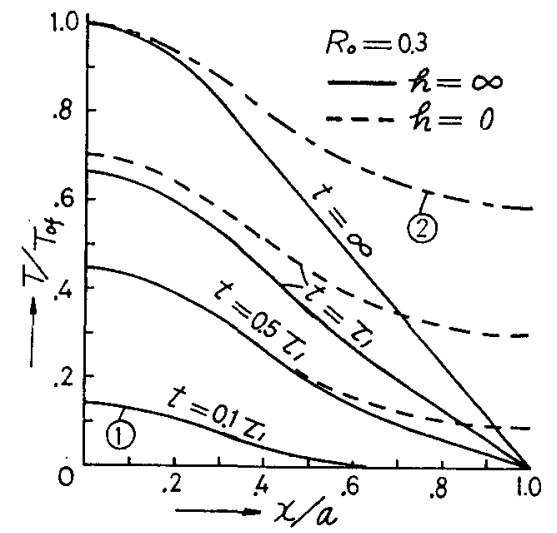

(b) $R_{0}=0.3$

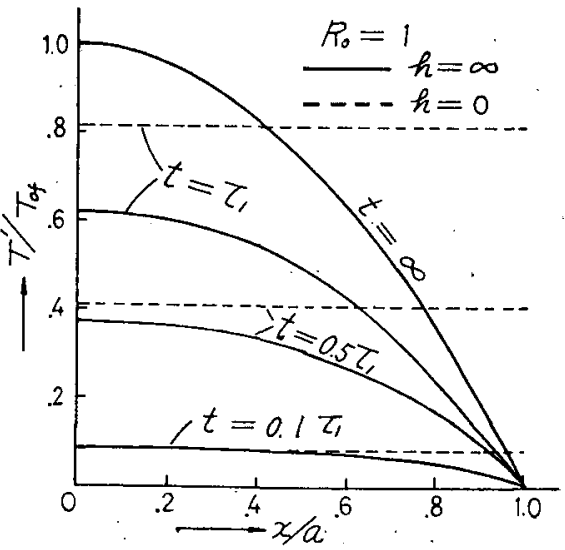

(d) $R_{0}=1.0$

第14図 持続熱源の場合の温度分布 
(4·3）式に見る通りであり，図にはそれぞれの場合の $T_{0 f}$ を基準にして $T / T_{0 f}$ を示している。)

まず簡明な $R_{0}=0$ の場合すなわち熱が $x=0$ 端面に 集中的に加えられる場合（Fig. 14（a)）について述心゙ る.

\section{(c-1) $\boldsymbol{R}_{\mathbf{0}}=0$ の場合（Fig. 14(a))}

Fig. 14(a) の実線は $h=\infty$ の場合で， $t=\infty$ では図 に見るように $x$ に沿う温度分布は直線的となる（4·14） 式. (4·16) 式を $h=\infty, R_{0}=0$ の場合についてかくと

$$
\begin{aligned}
\frac{T}{T_{0 f}=} & \frac{8}{\pi^{2}}\left[\cos \left(\frac{\pi x}{2 a}\right) \cdot\left(1-e^{-t / \tau_{1}}\right)\right. \\
& +\frac{1}{9} \cos \left(3 \frac{\pi x}{2 a}\right) \cdot\left(1-e^{-t / \tau_{3}}\right) \\
& \left.+\frac{1}{25} \cos \left(5 \frac{\pi x}{2 a}\right) \cdot\left(1-e^{-t / \tau_{5}}\right)+\cdots\right] \cdots
\end{aligned}
$$

となる. $t=\tau_{1}$ の時刻を考えると，上式第 2 項 $(m=3)$ の $\tau_{3}$ は $(3 \cdot 13)$ 式により $\tau_{3}=\tau_{1} / 9$ であり，指数項は

$$
e^{-t / \tau_{3}}=e^{-9}=0.0001
$$

であり，実用上0である，したがって過渡項としては第 1 項のみが残り，

$$
\begin{aligned}
\frac{T}{T_{0 f}} & =\frac{8}{\pi^{2}}\left[\cos \left(\frac{\pi x}{2 a}\right)+\frac{1}{9} \cos \left(3_{2 a}^{\pi x}\right)\right. \\
& \left.+\frac{1}{25} \cos \left(5_{2 a}^{\pi x}\right)+\right]-\frac{8}{\pi^{2}} \cdot \cos \left(\frac{\pi x}{2 a}\right) \cdot e^{-t / \tau_{1}}
\end{aligned}
$$

上式の初めの項は定常温度分布であり，(4・14）式に 等しい: すなわち上式を書改めると， $t>\tau_{1}$ では

$$
\frac{T}{T_{0 f}}=\left(1-\frac{x}{a}\right)-\frac{8}{\pi^{2}} \cdot \cos \left(\frac{\pi x}{2 a}\right) \cdot e^{-t / \tau_{1}} \cdots
$$

上に述べる所からわかるように Fig. 14(a) の実線の $t=\tau_{1}$ 曲線之 $t=\infty$ 曲線（直線）との差は上式の第 2 項 で与えられ，乙の差の $x$ に浴う分布は cosine となって いる.

$t=0.5 \tau_{1}$ の時刻においても $m \geqslant 3$ の過渡項はやはり ほとんじ零になっており， $t=\infty$ の直線との差はほぼ cosine の形になっている.

$t=0.1 \tau_{1}$ の曲線は（4.24）式によって論考することは 困難で，後に（e）項に述べる. 乙の時期では $x=0$ に 投与された熱はいまだ $x=a$ 点にはほとんよ゙到達してい ない。

次に $h=0$ の場合 (点線) 飞ついてであるが， $t=$ $0.1 \tau_{1}$ の時刻では 熱はいまだ $x=a$ には達していな いので, $x=a$ 点の境界条件の差 $(h=0, \infty)$ は効かず, 温度分布は $h=\infty$ の場合 (実線) と実用上差がない。 ただ $t=0.5 \tau_{1}$ になると，図に見るように多少の差が生 ビてくる。
（4·16）式を $R_{0}=0, h=0$ の場合についてかくと*

$$
\begin{aligned}
\frac{T}{T_{0 f}^{-}}= & \frac{4}{\pi^{2}} \cdot \frac{t}{\tau_{1}}+\frac{8}{\pi^{2}}\left[\frac{1}{4} \cos \left(2 \frac{\pi x}{2 a}\right)\left(1-e^{-t / \tau}{ }_{2}\right)\right. \\
& \left.+\frac{1}{16} \cos \left(4 \frac{\pi x}{2 a}\right)\left(1-e^{-t / \tau_{4}}\right)+\cdots\right] \cdots(
\end{aligned}
$$

今 $t=\tau_{1}$ の時刻を考えると，上式の $\tau_{2}$ は $\tau_{2}=\tau_{1} / 4$

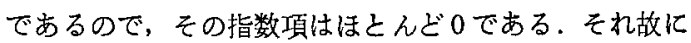
上式の第 2 項以下は

第 2 項以下 $=\frac{8}{\pi^{2}}\left[\frac{1}{4} \cos \left(2 \frac{\pi x}{2 a}\right)+\frac{1}{16} \cos \left(4 \frac{\pi x}{2 a}\right)+\cdots\right]$

となり，温度㤌第 1 項のみによって上昇する。

一方 $(4 \cdot 7)$ 式において $x_{0 \rightarrow 0}\left(R_{0} \rightarrow 0\right)$ の場合の温 度 $\Delta T$ は

$$
\frac{\Delta T}{T_{0 f}}=\frac{1}{2}\left(1-\frac{x}{a}\right)^{2}
$$

となるが，乙れをフーリェ級数化展開すると

$$
\begin{array}{r}
\frac{1}{2}\left(1-\frac{x}{a}\right)^{2}=\frac{1}{6}+\frac{8}{\pi^{2}} \sum \frac{1}{m^{2}} \cos \left(m \frac{\pi x}{2 a}\right) \\
(m=2,4,6 \cdots)
\end{array}
$$

上式の $x=0$ 点の值は $1 / 2$ であるから，上式から

$$
{ }_{\pi^{2}}^{8} \sum_{m^{2}} \frac{1}{2} \cos \left(m \frac{\pi x}{2 a}\right)=\frac{1}{2}-\frac{1}{6}=\frac{1}{3} \ldots
$$

したがって $t=\tau_{1}$ の時刻に占ける $x=0$ 点の温度は

$$
\frac{T}{T_{0 f}}=\frac{4}{\pi^{2}} \cdot \frac{\tau_{1}}{\tau_{1}}+\frac{1}{3}=0.738
$$

となる. Fig. 14(a) 参照.

次に Fig. 14(a) の㔹線(2)は $x=0$ の温度を $T_{0 f}$ と して (4.26) 式を描いたもので, その時刻 $t$ は (4-28) 式から

$$
\begin{aligned}
& \frac{4}{\pi^{2}} \frac{t}{\tau_{1}}=1-\frac{8}{\pi^{2}} \sum \frac{1}{m^{2}} \cos \left(m \frac{\pi x}{2 a}\right)=1-\frac{1}{3} \\
& \therefore \frac{t}{\tau_{1}}=\frac{2}{3} \cdot \frac{\pi^{2}}{4}=1.64
\end{aligned}
$$

\section{(c-2) $\boldsymbol{R}_{0}=1$ の場合 (Fig. 14(d) 参照)}

これは $x=0 \sim a$ の全域に発熱のある場合であるが， まず $h=\infty$ の場合を考える。

$\boldsymbol{h}=\infty$ の場合** 乙の場合の $T_{0 f}$ は $(4 \cdot 3)$ 式から

$$
T_{0 f}=q a^{2} / 2 K
$$

となり，との值は全発熱量が $x=0$ 点に集中した場合の $T_{0 f}$ の $1 / 2$ である. 定常状態の温度分布は (4·2) 式から

$$
\underset{T_{0 f}}{T}=1-\frac{x^{2}}{a^{2}}
$$

* $R_{0} \rightarrow 0$ となると, $\sin \left(m \frac{\pi}{2} R_{0}\right) \rightarrow m \frac{\pi}{2} R_{0}$

$(4 \cdot 18)$ 式において上の関係を利用すると，(4·16) 式は（4·26）式となる。

** 乙の場合の温度分布, 温度変化については すでに 文献 (2) (点溶接における板中の温度変化) 飞論 若してある。 
となり，分布曲線はパラボラ形となる．Fig. 14 (d) の $\boldsymbol{t}=\infty$ の曲線.

過渡現象的の温度变化は $(4 \cdot 16),(4 \cdot 18)$ 式において $R_{0}=1$ とおいて $(m=1,3,5 \cdots)$

$$
\begin{aligned}
\frac{T}{T_{0 f}^{-}=} & \frac{32}{\pi^{3}}\left[\cos \left(\begin{array}{c}
\pi x \\
2 a
\end{array}\right) \cdot\left(1-e^{-t / \tau_{1}}\right)\right. \\
& \left.-\frac{1}{27} \cos \left(3 \frac{\pi x}{2 a}\right) \cdot\left(1-e^{-t / \tau_{3}}\right)+\cdots\right] \cdots
\end{aligned}
$$

上なる. $m=3$ 項はその振幅が基本波 $(m=1)$ 亿出べて (1/27) 倍となり，小さいので， $x$ に浴う温度分布は大 体 cosine 波形亡なる。（つまり Fig. 14(d) の $t=\infty$ なるパラボラ曲線はすでに大体 cosine に近い)

さて Fig. 14(d) において $t=0.1 \tau_{1}$ の曲線をみる 之, $x=(0 \sim 0.5) a$ の部分では大体水平線で, $h=0$ の場 合の点線に一致している。乙れは熱が $x=0 \sim a$ の全域 に発生し、ただ $x=a$ 点からのみ伝導し去るが, $t=0.1$ $\tau_{1}$ の時刻では $x=(0 \sim 0.5) a$ の発熱は $x=a$ の方へ伝 導する暇がなく、これがため等斉な温度上昇となるので ある

$\boldsymbol{h}=0$ の場合 この場合は $\boldsymbol{x}=\boldsymbol{a}$ 点が熱絶縁されてい るので, $x=0 \sim a$ の発生熱はそのまま発生点の温度上昇 に費やされる.つまり (4.8) 式の $\Delta T$ は零で, (4.18) 式の $B_{m}$ も零で (Fig. 10(b) の $R_{0}=1$ の場合参照), 温度分布曲線は四の点線のような水平線となる。温度 は時間ととあに上昇し，その上昇速度は $q / c \sigma$ であるか ら, $t=\tau_{1}$ の時刻では温度は

$$
(q / c \sigma) \cdot \tau_{1}
$$

となる.これを $T_{0 f}$ と比べると

$$
\frac{\frac{q}{c \sigma} \cdot \tau_{1}}{T_{0 f}}=\frac{q \sigma \cdot \frac{q a^{2}}{k \pi^{2}}}{\frac{q a^{2}}{2 K}}=\frac{8}{\pi^{2}}
$$

よなる、罒の $t=\tau_{1}$ の点線の高さは上式に見るように $8 / \pi^{2}=0.810$ である.

(c-3) $\boldsymbol{R}_{0}=0.5,0.3$ の場合 (Fig. $14(\mathrm{~b}),(\mathrm{c})$ )

これらの場合は 上に述べた $R_{0}=0$ の場合と $R_{0}=1$ の場合の中間となる，曲線の傾向は定性的にはよくうな ずき得る所である。

\section{（d）持続加熱の場合の温度上昇速度}

$x=0 \sim x_{0}$ の領域に $q$ なる発熱を持続的に投与する場 合の温度上昇は（4·16）式で与えられる。したがって温 度上昇速度は $(4 \cdot 16)$ 式を $t$ について微分した形で与え られる。しかるに(4.16) 式は (3.15) 式を積分して得 たあのであるから，上昇速度は $(3 \cdot 15)$ 式に比例するこ とになる。

睤揭 Fig. 12 は $x_{0} / a=0.5$ の婸合の二三の将刻 $\left(t / \tau_{1}=0,0.01,0.1,1\right)$ における温度分布を示してい るが，乙の曲線の高さは 上に述べる所からわかるよう に $x=0 \sim x_{0}$ の領域に一定発熱 $q$ が持続して与えられ たときの舅度上昇速度を示しているととになる。

\section{（e）映像法による計算}

前項までは 板幅 $a$ なる平板の一次元熱伝導をフー リ土級数によって取扱うことについてであるが，本稿に 論じた $h=0, h=\infty$ のような簡明な場合は フーリェ 級数によらず， $a \rightarrow \infty$ とした無限板の場合の熱伝導の公 式を用い，いわゆる咉像法によって求めることもでき る.これは時間があまり経過していない状態に一Fig. 14 おいて $t=0.1 \tau_{1}$ のような曲線一一を求める場合に 便利である。

今 簡単のため 発熱が Fig, 1 のAA な端面に 集中的に与えられる場合 $\left(x_{0} \rightarrow 0, q x_{0} \rightarrow q_{0}\right)$ について述 ベるに，無限板の場合の温度の公式は次式で与えられ る1).

$$
T=\frac{q_{0}}{K} x \cdot\left[\frac{1}{\sqrt{\pi}}=\cdot \frac{e^{-\beta^{2}}}{\beta}-\{1-\Phi(\beta)\}\right]
$$

ただし

$$
\beta=\sqrt{x^{2} / 4} k t
$$

したがって，乙れを板幅が $a$ なる有限板の場合の $x=0$ 点の最終温度上昇 $T_{0 f}(4 \cdot 14)$ 式と比較する之,

$$
\frac{T}{T_{0 f}}=\frac{x}{a}\left[\frac{1}{\sqrt{\pi}} \cdot \frac{e^{-\beta^{2}}}{\beta}-\{1-\Phi(\beta)\}\right] \cdots \cdots(4 \cdot 37)
$$

上式の $\beta$ は $(4 \cdot 36)$ 式のとおりであるが，今

$$
t / \tau_{1}=g
$$

とおき， $x=a$ 点の $\beta$ を $\beta_{a}$ とおくと，

$$
\beta_{a}^{2}=\frac{a^{2}}{4 k t}=\frac{a^{2}}{4 k g \tau_{1}}=\frac{1}{g} \cdot \frac{\pi^{2}}{16}
$$

他の任笖の $x$ 点についての $\beta$ は

$$
\beta^{2}=\beta_{a}^{2} \cdot \frac{x^{2}}{a^{2}}
$$

Fig. 15 の奏線は $g=1\left(t=\dot{\tau}_{1}\right)$ の特刻における温度

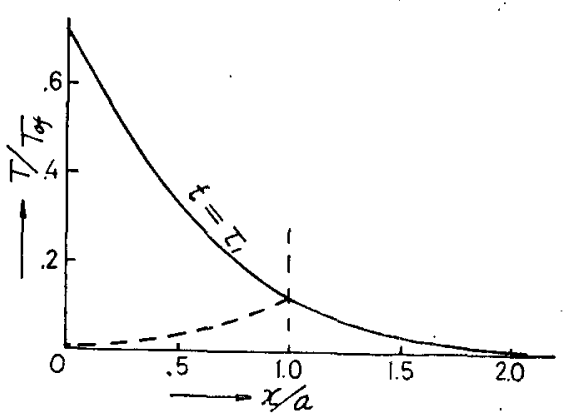

第15図 板幅加哭限大の堨合の温发分布 
分布を計算したものである*. 点楾は眏像法のためのも の. 後述.

Fig. 17 は 板幅が $a$ なる場合の温度を映像法似よ って求めるための説明図である。乙てでは端面 AA に q0なる投熱がある場合を考えており，（a）图に括いて 端面 $\mathrm{BB}$ 汇対して AA の映像の点 $\mathrm{A}^{\prime} \mathrm{A}^{\prime} に+q_{0}(h=0$ の場合）あるいは $-q_{0}(h=\infty)$ なる咉像熱源を仅想す る.

（b）罒は端面 AA にのみ発熱 $q_{0}$ がある場合の無限 板における ある時刻 $t$ にお゙ける温度分布であるとす る*.

（c) 図は $h=\infty$ の場合で，曲線(1)は（b) 図の曲 線 (1)部分， (2) は（b) 因の曲線(2)部分を逆転したもの で，(3’はその続きである. (2)が反対符号になっている のは（a）因の映像として - $q_{0}$ を考えているからであ るが，(3) む反対符号なのは 端面 AA では一定発熱 $q_{0}$ のみがあって， $\mathrm{A}^{\prime} \mathrm{A}^{\prime}$ にある $-q_{0}$ (映像)に上る熱は AA にては全反射されるからである。

* Fig. 15 のような曲楾は 誤差函数表によって数值 を計算する必要上, 種々なる時斛 $t(\beta)$ についての 曲線を描くことは手数を要して面倒である。しかし これは次のように一つの曲線が描加れれば，他は容 易に描くことができる.すなわち Fig. 16 において

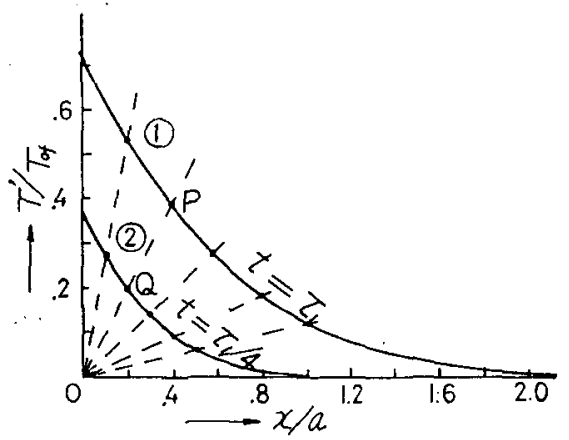

第16図 ある時刻 $t$ 亿おける分布曲線が既畑 ならば，他の時刻における分布曲線 (2)は作図によって求められる。

曲線(1)をある時刻 (ここでは $t=\tau_{1}$ )における温度分 布曲線であるとすると，他の時刻に招ける分布曲線 (2)は次のようにして求められる.今 $\mathrm{P}$ 点を曲線(1)上 の点であるとすると， P点と原点Oと直線で結び， $\mathrm{O} \overline{\mathrm{P}}$ 上KQ点をとり，加りに $\overline{\mathrm{OQ}}$ 之, $Q$ 点は $t=\tau_{1} / 4$ 亿おける温度分们曲楾上の点 を与える.何となれば，Q己 $\mathrm{P}$ と $x$ 坐標は $1: 2$ の関係にあるので, 時間の関係を 1：4の関係にお けば， $(4 \cdot 36)$ 式の $\beta$ は両者において等しくなり， 温度は (4-37) 式に見るように $(x / a)$ に比例し, 1：2の関係汇ある。乙れは上の作図による $\mathrm{P} ， \mathrm{Q}$

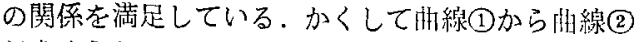
が求められる。

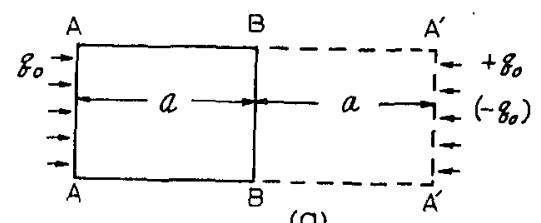

(a)

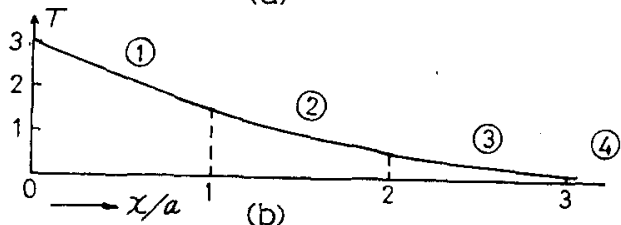

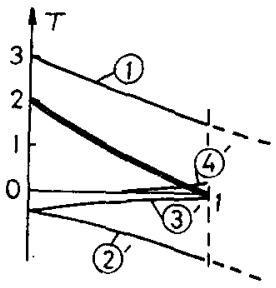

(c)

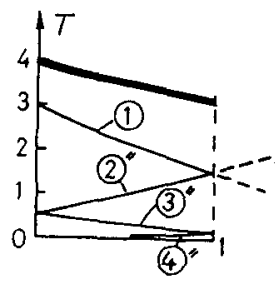

(d)
第17図 映像法による温度の計算説明図

（d）図は $h=0$ の場合で，熱は BB で全反射され， 反射された熱は AA に拈いても（c）の場合と同様反 射される。（c)，(d）図において太実線が合成温度で ある。

無限板について $t=\tau_{1}$ 時刻についての温度は Fig. 15 のようであり， $x=0, a, 2 a$ の温度は次のようになる。

$\begin{array}{lcccc}x / a & 0 & 1 & 2 & 3 \\ T / T_{0 f} & .718 & .127 & .009 & 0\end{array}$

それ故に $h=\infty$ の場合の $x=0$ 点の温度は $0.718-0.009-0.009=0.700 \cdots \cdots \cdots \cdots(4 \cdot 41)$

また $h=0$ の場合の $x=0, x=a$ の温度は $\left.\begin{array}{ll}x=a & 0.127+0.127=0.254 \\ x=0 & 0.718+0.009 \times 2=0.735\end{array}\right\}$

\section{V 熱放散を考えた場合}

前節までに䢞べる所は 板表面からの熱放散を無視し ている．板表面加らの熱放散を考慮に入れると，当然 温度上昇は低く計算される.抵抗溶接の場合は別上して アーク溶接の母板の温度上昇の問題に対しては 板表面 加らの熱損失は後に明かとなる上うに無視し得ない重大 な影響を与元る。

\section{（a）温度の基本式 一熱を瞬間的に投与した場合一}

板の温度上筷があまり大したあのでない場合には 表 面からの熱放散は温度上昇 (外界上の温度差) $T$ 亿比例 すると考えてよく，温度に関する基本方程式は

$$
\frac{\partial T}{\partial t}=k \cdot \frac{\partial^{2} T}{\partial x^{2}}-b T
$$


なる形にかける3).上式の解として，今

$$
T=e^{-b t} \cdot \phi(x, t)
$$

とおいて，てれを（5·1）式に代入してみると，

$$
\partial \phi=k \cdot \frac{\partial^{2} \phi}{\partial x^{2}}
$$

を得る。乙れは熱放散のない場合の基本式 $(3 \cdot 1)$ 式と 同じ形である.したがって熱放散のある場合の温度は ない埸合の温度の解一正節に求めたもの一飞 を乗ずればよいこととなる゙3.

\section{（b）熱の放散係数——熱放散の時間定数}

(5·2) 式に見るように $b$ は $(1 / \mathrm{sec})$ の次元を有して いるので，今ての逆数を若え，

$$
1 / b=\tau_{\text {rad }}
$$

とかくと, $(5 \cdot 2)$ 式の指数項は

$$
e^{-b t}=e^{-t / \tau} \mathrm{rad}
$$

とかける， $\tau_{\mathrm{rad}}$ は熱放散に関する時間定数である。

さてての $b\left(=1 / \tau_{\mathrm{rad}}\right)$ の值についてであるが，板表 面からの放散能を $\alpha \mathrm{cal} / \mathrm{cm}^{2} \cdot \mathrm{sec} \cdot{ }^{\circ} \mathrm{C}$ とし, 熱放散は板 の表赛両面に生ずるすのとし， $d$ を板厚とすると，

$$
b=\frac{\alpha}{c \sigma} \cdot \frac{2}{d}
$$

とかける。今

$$
\alpha=10^{-3} \mathrm{cal} / \mathrm{cm}^{2} \cdot \mathrm{sec} \cdot{ }^{\circ} \mathrm{C}
$$

とし*. $c \sigma=1 \mathrm{cal} / \mathrm{cm}^{3} \cdot{ }^{\circ} \mathrm{C}, d=2 \mathrm{~cm}$ とすると

$$
\begin{aligned}
\tau_{\text {rad }} & =\frac{1}{b}=\frac{c \sigma}{\alpha} \cdot \frac{d}{2} \\
& =\frac{1}{10^{-3}} \cdot \frac{2}{2}=10^{3} \quad(\mathrm{sec})
\end{aligned}
$$

となる．今との $\tau_{\mathrm{rad}}$ を板中の熱伝導に関する時定数と 此較するに， $\tau_{m}$ のうち $\tau_{1}$ は (3.9) 式に見るように

$$
\tau_{1}=\frac{4 a^{2}}{\pi^{2} k}
$$

である、今母板寸法として $a=10 \mathrm{~cm}$ とし， $k=0.1$ $\mathrm{cm}^{2} / \mathrm{sec}$ とすると

$$
\tau_{1}=4 \times 100 \div\left(\pi^{2} \times 0.1\right) \doteqdot 400(\mathrm{sec}) \cdots \cdots(5 \cdot 10)
$$

となる。乙れは（5.7）の $\tau_{\mathrm{rad}}$ と似た值である。 $\tau_{\mathrm{rad}}$ は板暻 $d$ によって比例的に変化し, 薄板では小さな值と なり，更よりむ小さな値となることが容易に起り得る ことは大いに注目に値する。

(c) 熱を瞬間的に投与した場合の温度

熱を $t=0$ の時刻に瞬間的に投与した埸合に，表面か らの熱損失がない場合の温度は (3・15) 式で与えられる から，熱損失がある場合の温度上昇 $T^{\prime}$ は $(5 \cdot 2)$ 式に よって次の形にかける。（熱損失を考えた場合の温度上

* (5.7) 式の $\alpha$ は黒体加らの熱楅射よりも一般に大之 なる，対流によるもので3，風があればさらに大と なる。
昇を $T^{\prime}$ として記し，前節までに求めた $T$ と区別して 示す)

$$
\begin{aligned}
T^{\prime} & =T_{0} \cdot e^{-t / \tau_{\mathrm{rad}}} \cdot\left[A_{0}+\sum A_{m} \cos \left(\frac{m \pi x}{2 a}\right) \cdot e^{-t / \tau_{m}}\right] \\
& =T_{0}\left[A_{0} \cdot e^{-t / \tau_{\mathrm{rad}}}+\sum A_{m} \cos \left(\frac{m \pi x}{2 a}\right) \cdot e^{-t / \tau_{m m^{\prime}}}\right]
\end{aligned}
$$

ただし

$$
\tau_{m}^{\prime}=\frac{\tau_{m} \cdot \tau_{\mathrm{rad}}}{\tau_{m}+\tau_{\mathrm{rad}}}
$$

今

$$
\tau_{1} / \tau_{\mathrm{rad}}=f
$$

とおくと，上の $\tau_{m}^{\prime}$ は (3・13) 式によって次のようにな る.

$$
\tau_{m}{ }^{\prime}=\tau_{1} /\left(m^{2}+f\right)
$$

すでに（b）項に述べたように板寸法のいかん似よっ ては $\tau_{\mathrm{rad}}$ は $\tau_{1}$ に近い值あるいはさらに小さな值（b が大）となり，熱放散がある場合は温度は急速に低下す ることとなる，次に述べる持続熱源の場合参照.

（d）持続熱源の場合一一の 1 一定常温度上昇

板表面加らの熱放散を無視すると， $h=0$ の場合には 温度は時間亡よもにドンドン上昇するが，熱放散を考え ると $h=0$ です無限には上昇しない.

Fig. 18 の $t=\infty$ なる曲線は (5.13) 式の $f$ を $f=1$ として定常温度上昇の分布を後佂示す理論式加計算し たあので（a）は $R_{0}=0$ すなわち熱が Fig. 1 の AA 端面にのみ発生した場合，(b) は $R_{0}=1$ すなわち熱が $x=0 \sim a$ の全面㳊等斉に発生持続した場合を示してい る.ここでは紙数の関係もあり，てれら $R_{0}=0,1$ の場 合に限定して考えることとし，まず $t=\infty$ なる定常温 度上昇について述べる。

\section{$\boldsymbol{R}_{0}=0$ の場合（熱を $\boldsymbol{x}=0$ 端面に集中投与）}

$x=0$ 倠面に $q_{0}$ なる熱が $t=0 \sim t$ にわたって投与ささ れる場合の定常温度上昇は次のようになる*。 $h=\infty$ の場合 :

$$
T_{f}^{\prime}=\frac{q_{0}}{r K} \cdot \frac{1}{e^{2 \gamma a}+1}\left(e^{\gamma(2 a-x)}-e^{\gamma x}\right)
$$

$h=0$ の場合 :

$$
T_{f}^{\prime}=\frac{q_{0}}{\gamma} \cdot \frac{1}{e^{2 \gamma a}-1}\left(e^{\gamma(2 a-x)}+e^{\gamma x}\right)
$$

ただし

* 乙の場合には基本式は（5.1）式の左辺を零とした あのに等しく（何となれば, $x$ 亿沿う発熱は零 $q=0$. 後揭 $(5 \cdot 27)$ 式参照), $(5 \cdot 15),(5 \cdot 16)$ 式は てれを満足している． $x=a$ 点の境界条件は（3・4）， (3.5) 式であり， $x=0$ 点の条件は

$$
-K \cdot \frac{\partial T}{\partial x}=q_{0}
$$

であるが，てれらを満足しているから正解である。 


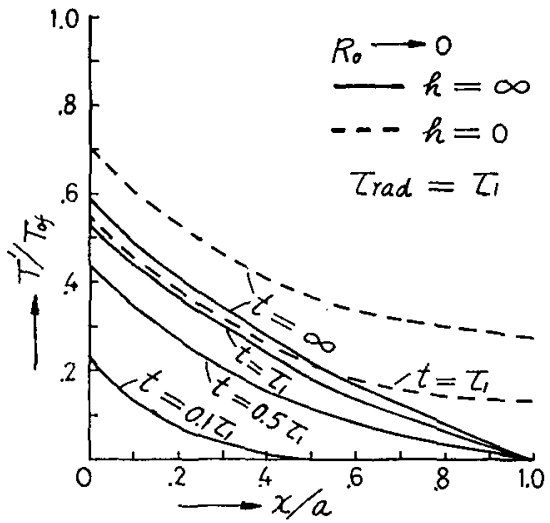

(a) $R_{0}=0$ の場合

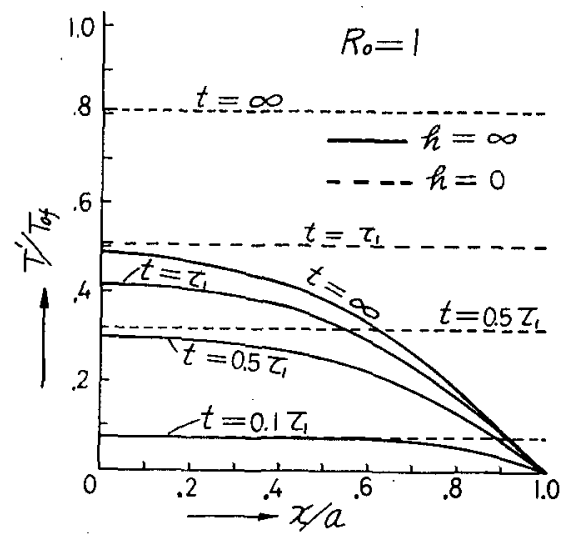

(b) $R_{0}=1$ の場合

第18図 表面からの熱放散を考虑した場合の温度分有（ $\tau_{\mathrm{rad}}=\tau_{1}$ と仮定している.）

$$
r=\sqrt{b / k}
$$

さて (5.17) 式の $\gamma$ の值は $(5 \cdot 4),(5 \cdot 13),(3 \cdot 9)$ 式 を代入すると

$$
\begin{aligned}
& r=\sqrt{f} \cdot \pi / 2 a \\
& \therefore 2 a r=\sqrt{f} \cdot \pi
\end{aligned}
$$

したがって今 $f=1$ として $x=0$ 点の $T_{f}^{\prime}$ の值 $T_{0 f}^{\prime}$ を計算し，てれを表面からの熱放散のない場合の $T_{0 f}$ (4-3) 式と比較してみると, $h=\infty$ の場合には

$$
\frac{T_{0 f}^{\prime}}{T_{0 f}}=\frac{2}{\pi} \cdot \frac{e^{\pi}-1}{e^{\pi}+1}=0.583
$$

となり， に沿う温度分布は

$$
\frac{T_{f^{\prime}}}{T_{0 f}}=0.583 \cdot \frac{e^{\pi(1-x / 2 a)}-e^{\pi x / 2 a}}{e^{\pi}-1}
$$

となる. Fig. 18(a) の $t=\infty$ の曲線 (実線) はこれを 示している*.

次に $h=0$ の場合には $T_{0 f}^{\prime}$ は $f=1$ とする上

$$
\frac{T_{0 f}^{\prime}}{T_{0 f}}=\frac{2}{\pi} \cdot \frac{e^{\pi}+1}{e^{\pi}-1}=0.695
$$

となり，xに浴う温度分布は

$$
\frac{T_{f^{\prime}}^{\prime}}{T_{0 f}}=0.695 \cdot \frac{e^{\pi(1-x / 2 a)}+e^{\pi x / 2 a}}{e^{\bar{x}}+1}
$$

となる. Fig. 18(a) 参照。

$R_{0}=1$ の場合（熱が $x=0 \sim a$ の全面に発生）

乙の場合の定常解は次のようになる**.

*乙の曲線の $x=0$ における傾斜は $(5 \cdot 18)$ 式にて規 穴されており，表面からの熱放散がない場合の曲線 (Fig. 14(a))の $t=\infty$ の曲線のそれに等しい， $x$ が 堌すに従って表面からの熱放散のために板中を右力 へ伝導する熱流が減少し，曲線の傾斜が低下する。

** 乙の場合の基本式は

$$
k \frac{\partial^{2} T}{\partial x^{2}}-b T+\frac{q}{c \sigma}=\frac{\partial T}{\partial t}=0
$$

である. (5.25)，(5.26) 式はこの基本式を満足し， 加 $x=0, x=a$ の境界条件を满压している加ら正 解である。

$$
\begin{array}{ll}
h=\infty: & T_{f}^{\prime}=\frac{q}{K} \cdot \frac{1}{\gamma^{2}}\left(1-\frac{e^{\gamma x}+e^{-\gamma x}}{e^{\gamma a}+e^{-\gamma a}}\right) \\
h=0 & : \quad T_{f^{\prime}}=\frac{q}{K} \cdot \frac{1}{\gamma^{2}}=\frac{q}{\sigma \sigma} \cdot \frac{1}{b} \quad \ldots .
\end{array}
$$

上式によって $x=0$ 点の温度 $T_{\text {of }}^{\prime}$ を求めると, $f=1$ の場合には

$$
\left.\begin{array}{ll}
h=\infty & T_{0 f}^{\prime}=0.487 T_{0 f} \\
h=0 & T_{0 f}^{\prime}=\frac{8}{\pi^{2}} T_{0 f}=0.810 T_{0 f}
\end{array}\right\}
$$

となる. Fig. 18(b) 参照.

\section{(e) 持秸熱源の場合一一の 2 一一過渡的变化}

板表面からの熱放散がない場合の温度は $(4 \cdot 16)$ 式で 与えられるが，熱放散がある場合の温度は (4·16) 式に $e^{-b t}$ を乗じたあのではない，熱損失がある場合の瞬間 投与の場合の式一 $(5 \cdot 11)$ 式を $t=0 \sim t$ について積分し たものが答で, $(5 \cdot 11)$ 式において $T_{0}$ を $q / c \sigma$ とおい て積分すると

$$
\begin{aligned}
T^{\prime}= & \frac{q}{c \sigma}\left[A_{0}\left(1-e^{-t / \tau_{\mathrm{rad}}}\right)\right. \\
& \left.+\sum A_{m} \cdot \tau_{m}{ }^{\prime} \cos \left(m \frac{\pi x}{2 a}\right) \cdot\left(1-e^{-t / \tau_{m^{\prime}}}\right)\right]
\end{aligned}
$$

となる. $(4 \cdot 16),(4 \cdot 21)$ 式など参照.

$\boldsymbol{R}_{0}=0$ の場合 とれを $h=\infty, 0$ について考える.

$\boldsymbol{h}=\infty$ 乙の場合には $m$ は $(3 \cdot 19)$ 式により $m=1,3$, 5 であるが，上式の $\tau_{m}^{\prime}$ を(5.14) 式によって $\tau_{1}$ を用 いて示し，加上式の定常項之過渡項とを分けて考える c,

$$
\begin{aligned}
\frac{T^{\prime}}{T_{0 f}}= & \frac{T_{f}(x)}{T_{0 f}}-\frac{8}{\pi^{2}}\left[\frac{1}{1+f} \cdot \cos \left(\frac{\pi x}{2 a}\right) \cdot e^{-(1+f) t / \tau_{1}}\right. \\
& \left.+\frac{1}{3^{2}+f} \cdot \cos \left(3 \frac{\pi x}{2 a}\right) \cdot e^{-(\theta+f) t / \tau_{1}}+\cdots\right]
\end{aligned}
$$

となる、ただし上式の $T_{f}^{\prime}(x)$ は定常項で，(5.29) 式 において $t=\infty$ とおいたあのであるが，乙れは（5・15） 
式で与えられる.

Fig. 18(a) には $t=(0.1,0.5,1) \tau_{1}$ の場合の分布曲 線を示しているが, $(f=1)$, 図において注目すべきは $t=\tau_{1}$ の曲線は $t=\infty$ の曲線とあまり差がない点であ る、乙れは表面からの熱損失があるので，温度が少し上 昇するとその上昇速度がいちじるしく減少するからで， 熱放散のない場合（Fig. 14(a)の $t=\infty, t=\tau_{1}$ の曲線） と相当に趣きを異にしている。 $t=0.1 \tau_{1}$ の曲線は 発 熱開始よりいまだあまり時間む経過しておらず，加そ の温度上昇值む低いので，熱放散を無視した場合の曲線 (Fig. 14(a) 参照)とほとんど差がない。

$$
\begin{aligned}
\boldsymbol{h}=0: & \text { この場合には } m=0,2,4 \cdots \text { となり, } \\
\widetilde{T_{0}^{\prime}}= & \frac{T_{f^{\prime}}(x)}{T_{0 f}}-\frac{8}{\pi^{2}}\left[\frac{1}{2} e^{-f t / \tau_{1}}\right. \\
& \left.+\frac{1}{2^{2}+f^{2}} \cos \left(2 \frac{\pi x}{2 a}\right) e^{-(4+f) t / \tau_{1}}+\cdots\right] \cdots(5)
\end{aligned}
$$

となる. Fig. 18(a) には $t=\tau_{1}$ の曲線を $f=1$ として 描いている。

$\boldsymbol{R}_{0}=1$ の場合 乙の場合も前述の $R_{0}=0$ の場合と似 た形としてかける.ただ（5.29）式の $A_{m}$ が $R_{0}$ 值に 上って異なるので, (3.23) 式 $m$, 次項の係数が異な る.

$$
\begin{aligned}
& \boldsymbol{h}=\infty \text { ：温度 } T^{\prime} \text { をそのまま誌すと } \\
& T^{\prime}=\frac{q a^{2}}{2 K} \cdot \frac{8}{\pi^{2}} \cdot \frac{4}{\pi}\left[\frac { 1 } { 1 + f } \cdot \operatorname { c o s } ( \frac { \pi x } { 2 a } ) \cdot \left(1-e^{\left.-(1+f) t / \tau_{1}\right)}\right.\right. \\
& -\frac{1}{3} \cdot \frac{1}{3^{2}+f} \cdot \cos \left(3 \frac{\pi x}{2 a}\right) \cdot\left(1-e^{\left.-(9+f) / \tau_{1}\right)}\right. \\
& +\cdots \cdots \cdots]
\end{aligned}
$$

一で，時間定数 $\tau_{\mathrm{rad}}$ にて指数函数的に上㫒する。

$$
\begin{aligned}
T^{\prime} & =T_{f} \cdot\left(1-e^{\left.-t / \tau_{\mathrm{rad}}\right)}\right. \\
& =T_{0 f} \cdot \frac{8}{\pi^{2}} \cdot \frac{1}{f^{\left(1-e^{-f t / \tau_{1}}\right)}} .
\end{aligned}
$$

Fig. 18(b)には $f=1$ として $t=\infty, \tau, 0.5 \tau$ など の温度を示している.

なお $t=\infty$ の高さは図代見るように $8 / \pi^{2}=0.81$ であ り，乙れは熱放散を無視した場合の $t=\tau_{1}$ における值 (Fig. 14(d) の $t=\tau_{1}$ 曲線) と一致している.とれは こてでは $f=1\left(\tau_{\mathrm{rad}}=\tau_{1}\right)$ と仮定しているからであるて とはいうまでもない。

\section{VI 結 言}

本稿は静止熱源による平板中の一一次元の熱伝導を主と してフーリェ級数によって取报ったもので，実際のアー ク溶接における母板の温度分布についての知見を得るこ とをねらいとしている。得られた結果の大要はグラフと しては Fig. 14, Fig. 18 に示しているが, 理論式とし ては温度変化を熱時間定数 $\tau_{1}, \tau_{m}$ で取扱い，表面から の熱放散も $\tau_{\mathrm{rad}}$ なる時間定数で取扱ったので，板自体 の熱伝導による温度変化之表面損失による温度変化との 関係を明仭化知ることができ，板寸法によって定まる $\tau_{1}, \tau_{\mathbf{r a d}}$ の任意の場合の考察が容易にできるようになっ ている，比較的小さな寸法の母板についてあ 表面から の熱放散は温度に大きく影響するととは注目に值する。

\section{引用 文 献}
1) 安蔽弘平：溶学誌 $39(1) 9(1970)$
2）安櫒・ 中村：溶接誌 26 (12) 742 (1957)

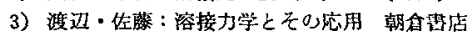

